\title{
QUALITY OF NURSING CARE PROVIDED FOR PRETERM INFANTS SUFFERING FROM RESPIRATORY DISTRESS SYNDROME
}

Ahmed Loutfy Abdullateif (a); Prof. Afkar Ragab Mohamed(b); Dr. Nabila Hassan

Abed.Ella(c); Dr.Rehab Hani Alkazaz(c)

(a) Demonstrator at Pediatric Nursing Department, Beni Suef University. (b) Prof. of Pediatric Nursing, Faculty of Nursing, Cairo University; (c) Lecturer ofPediatric Nursing, Faculty of Nursing, Port Said University;

\begin{abstract}
Preterm infants are at risk for respiratory distress syndrome which defined as a breathing disorder resulting from lung immaturity.Respiratory distress syndromeis a life-threatening lung disorder that results from underdeveloped and small alveoli and insufficient levels of pulmonary surfactant. Quality improvement is a major focus of neonatal health care. The present study aims to assess quality of nursing care provided to preterm infant with respiratory distress syndrome. A descriptive research design was utilized on48 neonatal nurses and 71 preterm infants. The nurses were working in the neonatal intensive care units of El-Nasr, ElTadamon, and Port-Fouad General hospitals in Port Said City. The data were collected using an interview questionnaire sheet for nurses and assessment data sheet for preterm infants. The study's results indicated that, less than two-thirds of the studied nurses had poor level of knowledge and more than half of them had poor level of practice. There was a highly statistical significant relation between the studied nurses' total knowledge mean scores and total practice mean scores with their educational level with $p \leq 0.001$. The study concluded that there was a highly statistical significant correlation between the studied nurses' total knowledge mean scores and their total practice mean scores. It was recommended that educational and training programs should be provided to neonatal nurses to improve their level of knowledge and practice through multidisciplinary approach that focus on the quality of nursing care provided to high risk neonates.
\end{abstract}

KEYWORDS: preterm infant, quality of care, respiratory distress syndrome, pediatric, nursing 


\section{INTRODUCTION:}

Respiratory distress syndrome, also known as Hyaline Membrane Disease (HMD), is a lifethreatening lung disorder that results from underdeveloped and small alveoli and insufficient levels of pulmonary surfactant(Schraufnagel, 2010).RDSis the single most important cause of morbidity in preterm infants, especially before 34 weeks gestation and is the most common cause of mortality(Dargaville \& Tingay, 2012).

High Risk Neonates (HRN) areneonates at greater risk of morbidity, neonatal intensive care unit (NICU) admissions, adverse neurological sequelae, and respiratory complications,particularly Respiratory Distress Syndrome (RDS)(Mally et al., 2010).European Foundation for the Care of Newborn Infants [EFCNI] (2014) stated that the risk of a neonatal death due to complications of preterm birth is about twelve times higher for an African neonate than for an European neonate.

Infants with RDS have poor lung compliance; they generally require mechanical ventilation and supplemental oxygen, leading to interstitial edema and epithelial destruction(Potts\&Mandleco, 2012). The overall effect of the disease process is a Ventilation-Perfusion (V/Q) ratio imbalance that leads to hypercapnia and hypoxemia(Jeenakeri \&Drayton, 2009). RDSpresents in the first four hours of life and is characterized by an increase in the respiratory rate more than 60 cycles per minute and dyspnea which is evident by nasal flaring and subcostal and/or sternal recession (Ricci \& Kyle, 2009).

The diagnosis of RDS is based on the clinical picture and x-ray findings(Mattson \& Smith, 2011). Tests used to evaluate fetal lung maturity are: PhosphatidylGlycerol (PG) is synthesized from mature lung alveolar cells and Lecithin/Sphingomyelin $(\mathbf{L} / \mathbf{S})$ ratio which are two phospholipids that are detected in the amniotic fluid(Chapman \&Durham, 2014). Medical management of the newborn with RDS is focused on continuous pulse oximetry, Arterial Blood Gases (ABG), The Partial Pressure of Oxygen in Arterial Blood $\left(\mathbf{P a O}_{2}\right)$ should be maintained in the normal range of 50 to $70 \mathrm{mmHg}$ and a pulse oximetry reading of 90\%. EndoTracheal Tube (ETT) and exogenous surfactant as indicated for neonates at risk for RDS(Bowden \& Greenberg, 2010).

Methods of respiratory support include:oxygen therapy by mask, hoodor cannula for neonates requiring short-term oxygen support, Continuous Positive Airway Pressure (CPAP) used for neonates, who are at risk for RDS(Morley et al., 2008). If untreated, RDS will worsen.It appears to be a self-limiting disease, with respiratory symptoms declining after 72 hours. This decline parallels the production of surfactant in the alveoli (McLenan, 2007). 
Nursing care of infant with RDS is demanding crucial part requiring alert, skillful, and sensitive nurse. The care involves, review the history for risk factors associated with RDS(London et al., 2014). Umbilical Arterial Catheter (UAC) may be used to draw arterial blood for monitoring oxygenation, suctioning should occur only when necessary through nasopharyngeal passage, the trachea or ETT, inspection of the skin and position changes with gel mattresses are helpful in guarding against skin breakdown(Hockenberry \& Wilson, 2011). The neonatal mortality rate reflects not only the quality of women care during pregnancy but also the quality of infants care during the first month of life(Pillitteri, 2010).Assessing and improving the quality of nursing care is a major focus of neonatal healthcare(Elverson $\&$ Samra, 2012). Quality of care is probably much more complex. Therefore, as nurses who are involved in quality improvement or implementation of evidence-based practice, must be faced with the question of how to measure quality of care (Alfaro-Lefever, 2013). Neonatal quality measures that have been examined include structural measures such as average daily census and outcome measures such as mortality and rates of complications of prematurity (Kaplan et al., 2011).

\section{Significance of the Study:}

In Egypt 2011, the prematurity rate was $7.4 \%$ (Blencowe et al., 2012) and the proportion of deaths from the complications of prematurity estimated by $45 \%$ of all neonatal death (Liu et al., 2012).Lissauer and Fanaroff (2011) highlighted that neonatal RDS is a one of the most common complications of prematurity. The largest NICU in Port Said report, El-Nasr Hospital Medical Records (2013) reported that, RDS represent $72 \%$ of all admitted cases to the NICU at 2012. Based on clinical experience in Port-Said NICUs, there were no studies that, assess quality of nursing care provided to preterm infants with RDS; hopefully the current study will illustrate the quality of neonatal nursing care especially for preterm infants with RDS.

\section{AIM OF THE STUDY:}

The aim of the current study was to assess quality of nursing care provided to preterm infant suffering from respiratory distress syndrome.

\section{The Research Questions}

1. What is the level of nurses' knowledge regarding care of preterm neonate with RDS?

2. What is the level of nurses' practice regarding care of preterm neonate with RDS?

3. 


\section{SUBJECTS AND METHOD}

A descriptive research design was utilizedin the current study.

\section{Sample:}

A convenient sample of 48 nurses working in Port Said NICUs during four months period and whose years of experience more than six (6)monthsin NICUs, and all preterm infants who were suffering from RDS, during the same period (71 preterm).

\section{Setting:}

The nurses were working in the neonatal intensive care units of El-Nasr, El-Tadamonand Port-Fouad General hospitals in Port Said City.

\section{Tool of data collection:}

Two tools were used to collect data for this study.

TOOL (I):A Structured Interview Sheet,This tool consisted of four parts: it was developed by the research investigators after reviewing the related literatures.

Part I: This part included personal data and professional characteristics of the studied nursesand data about characteristics of preterm infants with RDS

Part II:Nurses' knowledge regarding preterm infants with RDS and its nursing management,it contained forty seven(47) questions about care of RDS.

Part III:Nurses' knowledge regarding quality of nursing care for preterm infants suffering from RDS, it was contained six (6) questions.

Part IV:Nurses' knowledge regarding infection control policy for preterm infants suffering from RDS, it was contained eight (8) questions.

TOOL (II): Observation checklists to assess nurses' quality of care: were adapted from Ball et al.(2012); Bowden \& Greenberg (2012) and Nettina (2014).Certain modifications were done by the research investigator in the adapted checklists to suit the nature of the study.

\section{- Content Validity of the tools}

It was ascertained by seven experts in the field of pediatricnursing. Necessary modifications were done according to the experts' opinions.

\section{- Reliability of tools}

It was held on 5 nurses in the El- Nasr NICU. Cronbach's alpha coefficient was used to assess the internal consistency of knowledge and its value was (0.83).

\section{- Pilot Study}

A Pilot study included 5 nurses working at NICU at El- Nasr General Hospital. The purpose of the pilot study was to test applicability, clarity, relevance and feasibility of the study tools 
and sequence of quotations to maintain consistency. The nurses in the pilot study were excluded from the final subjects of the study.

\section{- Field Work}

The field work was carried out from the start of October 2013 extended to the end of January2014.The research investigator was available at each study setting by rotation, three days per week during morning, afternoon and night shifts. Each nurse was individually interviewed to assess quality of nursing care through their knowledge about RDS using structured interview sheets within 20-30 minutes at the conference room or nurses' room of NICUs, while their nursing care practice was assessed by using observational checklists during their actual practice. Each preterm data was collected by the research investigator from the hospital medical records.

\section{- Ethical consideration:}

Each study subject had the freedom to be involved in the study or to withdraw at any time. oral consent was obtained from the parentsof the studied preterm infants before data collection ensuring complete privacy and total confidentially.

\section{- Statistical analysis}

Data were analyzed with SPSS version 16. The normality of data was first tested with onesample Kolmogorov-Smirnov test.Qualitative data were described using number and percent. Continuous variables were presented as mean \pm SD (standard deviation) for parametric data and median for non-parametric data. The two groups were compared with Student $t$ test (parametric data) and Mann-Whitney test $\mathbf{Z}$ test (non-parametric data).Analysis of Variance (ANOVA test) used for comparison of means of more than two groups. Pearsoncorrelation used for correlation between continuous parametric data.

\section{RESULTS:}

Table (1)showed that $77.1 \%$ of the studied nursesreportedincomplete answers about definition, risk factors, and causes of preterm infants with RDS. Also, more than half of the studied nurses (54.8\%) didn't know the meaning of quality of health care.

Table (2) showed that $66.7 \%$ of nurses' practice about pulse oximetry care had an average level. The mean scores of oxygen therapy, and ET suctioning were $30.42 \pm 2.95,39.73 \pm 5.45$ scores respectively.

Figure (1) showed that $60.4 \%$ had poor level in their total scores of practice followed by $39.6 \%$ had an average level. The same figure showed that, more than half of the studied 
nurses $(56.3 \%)$ had poor level in their scores of knowledge; while 35.4\% of them had average level.

Table (3)showed that mean scores of knowledge among nurses who had bachelor's degree was higher statistically significant than who had secondary school of nursing or technical institute of nursing degree with $\mathrm{p} \leq 0.001$.

Table (4)showed that mean scores of practice among nurses who had bachelor's degree was higher statistically significant than who had secondary school of nursing or technical institute of nursing degree with $p \leq 0.001$. The same table showed that there were no statistical significant relations between nurses' practice means scores in relation to the rest of items of other nurses' personal and professional characteristics.

It was evident that there were a highly statistical positive significant positive correlation between nurses' total knowledge mean scores and their total practice mean scores with $\mathrm{p} \leq$ 0.001 .

Table (1): Nurses' Knowledge about RDS and Quality at NICU (n=48)

\begin{tabular}{|l|c|c|c|c|c|c||}
\hline \multirow{2}{*}{ Knowledge about RDS } & \multicolumn{2}{|c|}{ Completeanswer } & \multicolumn{2}{c|}{ Incomplete answer } & \multicolumn{2}{c|}{ Didn'tknow } \\
\cline { 2 - 7 } & NO & \% & NO & \% & NO & \% \\
\hline Definition of RDS & 7 & 14.6 & 37 & 77.1 & 4 & 8.3 \\
\hline $\begin{array}{l}\text { Risk factors and Causes of } \\
\text { RDS }\end{array}$ & 9 & 18.8 & 37 & 77.1 & 2 & 4.2 \\
\hline $\begin{array}{l}\text { Definition of quality of health } \\
\text { care }\end{array}$ & 1 & 2.1 & 22 & 45.8 & 25 & 52.1 \\
\hline
\end{tabular}

Table (2) Mean Scoresof Nurses' PracticeRegarding Preterm Infants with RDS (n=48)

\begin{tabular}{|c|c|c|c|c|c|c|c|}
\hline \multirow{3}{*}{ Items } & \multirow{3}{*}{ Mean \pm SD } & \multicolumn{6}{|c|}{ Nurses' level of practice } \\
\hline & & \multicolumn{2}{|c|}{ Good } & \multicolumn{2}{|c|}{ Average } & \multicolumn{2}{|c|}{ Poor } \\
\hline & & No & $\%$ & No & $\%$ & No & $\%$ \\
\hline Pulse oximetry & $18.98 \pm 1.25$ & 16 & 33.3 & 32 & 66.7 & 0 & 0 \\
\hline Oxygen therapy & $30.42 \pm 2.95$ & 28 & 58.4 & 20 & 41.6 & 0 & 0 \\
\hline ET suctioning & $39.73 \pm 5.45$ & 6 & 12.5 & 41 & 85.5 & 1 & 2 \\
\hline
\end{tabular}

Fig. 1: Total Scores of Nurses' Knowledge and Practice Regarding Preterm Infants with RDS (n=48)

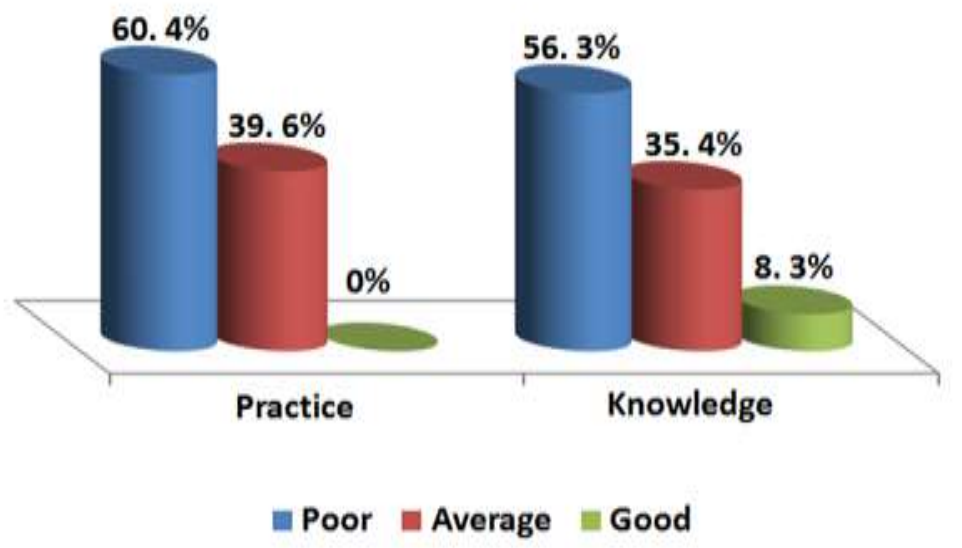


Table (3)Relation between Nurses' Knowledge Scores and their Personal and Professional Characteristics $(n=48)$

\begin{tabular}{|c|c|c|c|c|}
\hline Items & Mean \pm SD & Range & $\begin{array}{c}\text { Test of } \\
\text { sig }\end{array}$ & $\boldsymbol{P}$ \\
\hline \multicolumn{5}{|l|}{ Age } \\
\hline$-<20$ & 67 & 67 & \multirow{3}{*}{$\mathrm{F}=1.41$} & \multirow{3}{*}{$\begin{array}{l}.254 \\
\text { N.S }\end{array}$} \\
\hline$-20-<30$ & $75.8 \pm 9.9$ & $60-99$ & & \\
\hline$-\quad \geq 30$ & $69 \pm 3.7$ & $64-74$ & & \\
\hline \multicolumn{5}{|l|}{ Educational level } \\
\hline - $\quad$ Secondary school of nursing & $71.5 \pm 6.9$ & $60-87$ & \multirow{3}{*}{$\mathrm{F}=8.856$} & \multirow{3}{*}{$\begin{array}{c}.001 \\
* *\end{array}$} \\
\hline - $\quad$ Technical institute of nursing & $73.3 \pm 8.1$ & $64-88$ & & \\
\hline - $\quad$ Bachelor's degree in nursing & $83.5 \pm 10.6$ & $69-99$ & & \\
\hline \multicolumn{5}{|l|}{ Years of experience } \\
\hline$-\quad<5$ & $75.3 \pm 8.7$ & $64-94$ & \multirow{3}{*}{$\mathrm{F}=0.267$} & \multirow{3}{*}{$\begin{array}{l}.767 \\
\text { N.S }\end{array}$} \\
\hline$-5-<10$ & $75.2 \pm 11.1$ & $60-99$ & & \\
\hline$-\quad \geq 10$ & $72.4 \pm 7 . .9$ & $64-88$ & & \\
\hline \multicolumn{5}{|l|}{ Attending of training programs } \\
\hline$-\quad$ Yes $(16.7 \%)$ & $77.3 \pm 11$ & $67-99$ & \multirow{2}{*}{$\mathrm{t}=0.803$} & .426 \\
\hline$-\quad$ No $(83.3 \%)$ & $74.4 \pm 9.2$ & $60-99$ & & N.S \\
\hline
\end{tabular}

Table (4) Relation between Nurses' Practice Scores and Their Personal and Professional Characteristics $(n=48)$

\begin{tabular}{|c|c|c|c|c|}
\hline Items & Mean \pm SD & Range & Test of sig & $\boldsymbol{P}$ \\
\hline \multicolumn{5}{|l|}{ Age } \\
\hline$-\quad<20$ & 180 & 180 & \multirow{3}{*}{$\mathrm{F}=1.55$} & \multirow{3}{*}{$\begin{array}{l}.223 \\
\text { N.S }\end{array}$} \\
\hline$-\quad 20-<30$ & $198 \pm 19$ & $155-241$ & & \\
\hline$-\quad \geq 30$ & $186 \pm 6.7$ & 174-193 & & \\
\hline \multicolumn{5}{|l|}{ Educational level } \\
\hline - $\quad$ Secondary School of Nursing & $185.5 \pm 8.4$ & $155-197$ & \multirow{3}{*}{$\mathrm{F}=71.67$} & \multirow{3}{*}{$\underset{* *}{\leq 0.001}$} \\
\hline - $\quad$ Technical Institute of Nursing & $191.6 \pm 10.9$ & $179-210$ & & \\
\hline - $\quad$ Bachelor's Degree in Nursing & $223.2 \pm 9.4$ & $210-241$ & & \\
\hline \multicolumn{5}{|l|}{ Years of experience } \\
\hline$-<5$ & $197.0 \pm 21.4$ & $155-241$ & \multirow{3}{*}{$\mathrm{F}=0.64$} & \multirow{3}{*}{$\begin{array}{l}.532 \\
\text { N.S }\end{array}$} \\
\hline$-5-<10$ & $197.7 \pm 17.2$ & $179-232$ & & \\
\hline$->10$ & $188.8 \pm 9.7$ & $174-206$ & & \\
\hline \multicolumn{5}{|l|}{ Attending of training programs } \\
\hline$-\quad$ Yes $(16.7 \%)$ & $195.1 \pm 12.2$ & $186-221$ & \multirow{2}{*}{$\mathrm{t}=0.167$} & .868 \\
\hline - $\quad$ No $(83.3 \%)$ & $196.3 \pm 19.4$ & $155-241$ & & N.S \\
\hline
\end{tabular}




\section{DISCUSSION:}

The nursing role effectiveness model, based on Donabedian's framework, is supported by empirical evidence and can be used as a guide to examine the links among nursing structures, processes and patient outcomes (Doran, 2011). "Structure of care is a feature of a health care organization or clinician related to the capacity to provide high quality health care" (AHRQ, 2014). So, discussion firstly for the subjects' characteristics.

Quality of nursing care not depending only on nurses' knowledge and practice level but also depending on many factors such as the maturity of the preterm infants, birth weight and other associated problems. In the present study there were a highly statistical significant relation between improved and died cases (which represent $19.8 \%$ of all admitted cases with RDS) in relation to their gestational age and birth weight. A Chilean study by Mardones et al. (2008) recorded that, there were a statistical significant relation for the effects of neonatal birth weight and gestational age on the number of deaths and survivors, with a neonatal deaths' gestational age mean $31.96 \pm 6.06$ weeks.

Assess the studied nurses' knowledge and practice for preterm infants with RDS according to the process standard measures.Regarding to the studied nurses' knowledge about definition and causes of RDS, the present study showed that more than three-quarters of the studied nurses had incomplete answers. These findings were consistent with Mohammed (2010) who found that, about three-quarters of the studied nurses $(74.3 \%, 71.4 \%$ respectively) had poor knowledge about these items.

Concerning the studied nurses' knowledge about the function of surfactant, the present study showed that three-quarters of the studied nurses had incomplete answers. These findings of nurses' knowledge about definition, causes and diagnosis of RDS may be due to the complexity of RDS definition and pathophysiology. Also, there were no training program that emphasis on RDS as a critical neonatal disease.As regards the nurses' knowledge related to the concept of quality in health care, the current study revealed that, more than half of the studied nurses didn't know the definition of quality of health care. This reflected that the nurses were away from the concept of quality which considered the present and future for all fields especially at nursing specialty and the lack of continuing education for the nurses working in NICUs about quality of health care. The study done by Mustafa (2007) and found that, only one-quarter of the nurses had a correct score level of knowledge about the concept of quality.

The present study showed that, no one of the studied nurses had poor level of practice about applying pulse oximetry or oxygen therapy. The nurses' practice more developed in these 
procedures due to increase the rate of using oxygen therapy and pulse oximetry for preterm infants with RDS. These findings were convergent with $\boldsymbol{E l}$ sayed et al. (2013) who studied the establishing basic standards of nursing care protocol at neonatal intensive care unit, and found that, all nurses had competent level of performance in pulse oximetry or oxygen therapy care.

In relation to applying ET suctioning, the majority of the studied nurses had an average level of practice with some clear mistakes. For example, determining the negative pressure, the time of keeping the suction catheter in ETT, and using normal saline into ETT were the most common nurses' mistakes. This reflected that the studied nurses were away from the most updated guidelines for care of $H R N$ according to $A A R C$ (2010) suctioning guidelines. Parallel with Register (2002) who assessed neonatal suction techniques by registered nurses and found that only $19 \%$ of the nurses performing the suction procedure with between -50 to $-80 \mathrm{mmHg}$.

Outcome measures describe how the care delivered affects the neonate's health status (Elverson \& Samra, 2012). Regarding the studied nurses' level of knowledge; the findings of the current study showed that, more than half of the studied nurses had poor level in their scores of knowledge. This poor knowledge score findings may be attributed to the fact that nurses didn't emphasize for updating their knowledge about RDS by attending training programs. This finding was in accordance with Abou-zaid (2008) who found that, nurses' knowledge scores were generally low.

Concerning the studied nurses' level of practice about their actual care provided for preterm infants with RDS in the NICUs, as unexpected, the current study illustrated that, more than three-fifths of the studied nurses had poor practice level. These findings were congruent with Parajulee and Selvaraj (2011) who assessed the nurses' knowledge and performance about care given to newborn in NICU and concluded that there was lack in nurses' performance for care of newborns in NICU.

However the studied nurses mean age was $25.29 \pm 6.6$ years with mean years of experience of $5.73 \pm 3.25$ years, which considered the best age with very accepted years of experience to provide a high quality of nursing care, and supported by Mustafa (2007) who reported that the age group of nurses was between 20- $<25$ years old and Kunswa (2010) who found that the majority of the studied nurses had years of experience ranged from 5:10 years with mean $5.5 \pm 3.01$ years, there was no relation between nurses' age or years of experience with their level of knowledge and practice. It may be due to with increasing nurses' age, the ability to retaining knowledge decreased. This finding was in an accordance with the study finding of 
Sadek (2010) who applied evidence based guidelines for care of neonates with RDS, and contrary with Ahmed (2013) who found that there was a statistical significant relation between nurses' level of knowledge and their age. Also, this finding reflected that there was no relation with nurses' years of experiences due to keeping themselves away from the most updated procedures guidelines. On the other hand Abou Ahmed (2013) found that there was statistical significant relation between nurses' performance and years of experience.

The present study showed that, there was a highly statistical significant relation between total studied nurses' knowledge mean scores and their level of education with $p \leq 0.001$. This finding may be attributed to their curriculum which might include HRN assessment and complications of preterm infants such as RDS. This finding supported by Ahmed (2013) who found a statistical significant relation between nurses' knowledge and their level of education with $\mathrm{p}<0.05$.

The current study indicated that, there was a highly statistical significant relation between total studied nurses' practice mean scores and their level of education with $p \leq 0.001$. This could be related to acquiring more practical experience through in the bachelor degrees' curriculum which teaching practice as $60 \%$ of the study's hour, as well as being more familiar with medical terminology utilized in the unit. This parallel with Ahmed (2007) who found that the total score of adequate practices of bachelor degree nurses was higher than diploma nurses. While, Elsayed et al. (2013) stated that nurses with a diploma degree had higher performance than the bachelor degree.

The observation being held in the present study showed that there was a highly statistically significant correlation between total nurses' knowledge and their total practice with $p<0.001$. These results may be due to that the persons with requisite knowledge do the better professional practice to improving the quality of nursing care for preterm infants with RDS. Alkazaz (2010) supported this finding; while Sayed (2009) found that, there was no statistical significance relation between nurses' practice and knowledge.

\section{CONCLUSION:}

In the light of the main study findings, it was concluded that less than two-thirds of the studied nurses had poor level of knowledge and more than half of them had poor level of practice. In addition; there were a highly statistical significant relation between the studied nurses' total knowledge mean scores and their practice mean scores in relation to their educational level with $\mathrm{p} \leq 0.001$. There was a highly positive statistical significant 
correlation between the studied nurses' total knowledge mean scores and their total practice mean scores with $\mathrm{p} \leq 0.001$.

\section{RECOMMENDATION:}

Based on the findings of this study, our recommendation is:Periodic educational program for nurses working at NICUs is mandatory, for raising and updating the knowledge of nurses about quality of nursing care and its applications in care for preterms with RDS.

\section{REFERENCES}

Abou-Zaid, S. (2008). Quality of Nursing Care for High Risk Neonates Receiving Total Parental Nutrition (Unpublished Master Thesis). Faculty of Nursing, Ain Shams University, Egypt. pp: 77-81.

Agency for Healthcare Research and Quality [AHRQ]. (2014): Tutorials on Quality Measures. Retrieved May 30, 2014, 10:32 PM, from http://www.qualitymeasures.ahrq.gov

Ahmed, A. (2007). Assessment of Nursing Care Provided for Children Undergoing Hemodialysis (Unpublished Master thesis). Faculty of Nursing, Alexandria University, Egypt. pp. 69.

Ahmed, S. (2013). Compliance of Nurses with Neonatal Care Protocol Regarding Feeding in Neonates (Unpublished Master Thesis). Faculty of Nursing, Ain Shams University, Egypt. pp. 59-66.

Alfaro-Lefever, R. (2013). Critical Thinking, Clinical Reasoning and Clinical Judgment (5th Ed.). Philadelphia, PA: Saunders Elsevier. Chapter 6: Developing Interpersonal, Teamwork, and Selfmanagement Skills. pp. 207-238.

Alkazaz, R. (2010). Impact of Implementing Infection Control Program for Nurses to Control Nosocomial Infection in Neonatal Intensive Care Units in Port Said (Unpublished Doctoral Thesis). Faculty of Nursing, Port Said University. Egypt. pp. 92-108.

American Association for Respiratory Care [AARC]. (2010). AARC Clinical Practice Guideline: Endotracheal Suctioning of Mechanically Ventilated Patients with Artificial Airways 2010. Respiratory Care, 55(6), 758-764.

Ball, J., Bindler, R. \& Cowen, K. (2012). Clinical Skills Manual for Principles of Pediatric Nursing: Caring for Children (5 ${ }^{\text {th }}$ Ed.). USA: Julie Levin Alexander Publisher. pp. 64-67, 72-75, 134-137. 
Blencowe, H., Cousens, S., Oestergaard, M., et al. (2012). National, Regional and Worldwide Estimates of Preterm Birth Rates in the Year 2010 with Time Trends for Selected Countries Since 1990: A Systematic Analysis and Implications. The Lancet, 379(9832), 2162-2172.

Bowden, V., \& Greenberg, S. (2010). Children and their families: the continuum of care (2nd Ed.). Philadelphia, PA: Lippincott Williams \& Wilkins. Chapter 14: The Neonate with Altered Health Status. pp. 519-581.

Bowden, V., \& Greenberg, S. (2012). Pediatric Nursing Procedures (3 ${ }^{\text {rd }}$ Ed.). Philadelphia, PA: Lippincott Williams \& Wilkins. pp. 68-72, 188-193, 322-326, 450-457.

Chapman, L., \& Durham, R. (2014). Maternal-Newborn Nursing: the Critical Components of Nursing Care (2nd Ed.). Philadelphia, PA: F.A. Davis. Chapter 17: High-Risk Neonatal Nursing Care. pp. 335341.

Dargaville, P., \& Tingay, D. (2012). Lung Protective Ventilation in Extremely Preterm. Journal of Paediatrics and Child Health, 48(9), 740-746.

Doran, D. (2011). Nursing Outcomes: The State of the Science (2nd Ed.). UK: Jones \& Bartlett Learning Company. Chapter 1: Patient Outcomes as an Accountability. pp. 1-27.

El sayed, S., Sabry, Y., Sharkawy, H., Elsayed E., \& Ali, T. (2013). Establishing Basic Standards of Nursing care protocol at Neonatal Intensive care unit. Nature and Science, 11(4): 86-92.

El-Nasr Hospital Medical Records. (2013). El-Nasr NICU Annual Report. Egyptian Ministry Of Health.

Elsayed, L., El-Nagger, N., \& Aly, S. (2013). Nursing Care Provided for Neonates with Respiratory Distress Syndrome in the Neonatal Intensive Care Units at Makkah Al-Mukarramah in Saudi Arabia. Life Science Journal, 10(1), 3403-3412.

Elverson, C., \& Samra, H. (2012). Overview of Structure, Process, and Outcome Indicators of Quality in Neonatal Care. Newborn and Infant Nursing Reviews Journal, 12(3), 154-161.

European Foundation for the Care of Newborn Infants [EFCNI]. (2014). Caring for Tomorrow: EFCNI White Paper on Maternal and Newborn Health and Aftercare Services. Retrieved March 15, 2014, 06:05 AM, from http://www.efcni.org. 
Hockenberry, M., \& Wilson, D. (2011). Wong's Nursing Care Of Infants And Children (9th Ed.). Canada: Elsevier Mosby. Chapter 10: The High-Risk Newborn and Family. pp. 347-355.

Jeenakeri, R., \& Drayton, M. (2009). Management of Respiratory Distress Syndrome. Peadiatrics and Child Health, 19(4), 158-164.

Kaplan, H., Lorch, S., Pinto-Martin, J., Putt, M., \& Silber, J. (2011). Assessment of Surfactant Use in Preterm Infants as a Marker of Neonatal Intensive Care Unit Quality. BMC Health Services Research, 11(22), DOI: 10.1186/1472-6963-11-22.

Kunswa, A. (2010). Needs, Problems and Nursing Care of Newborn Infants (Unpublished Doctorate Thesis). Faculty of Nursing, Ain Shams University, Egypt. pp. 98-104.

Lissauer, T. \& Fanaroff, A. (2011). Neonatology at a Glance (2 ${ }^{\text {nd }}$ Ed.). Malden, MA: John Wiley. Chapter 26: Preterm Infants and their Complications. pp. 68-70.

Liu, L., Johnson, H.., Cousens, S., Perin, J., \& Scott, S. (2012). Global, Regional, and National Causes of Child Mortality in 2000-2010: An Updated Systematic Analysis. The Lancet, 379(9832), 21512161.

London, M., Ladewig, P., Davidson, M., Ball, J. Bindler, R., \& Cowen, K. (2014). Maternal \& Child Nursing Care (4th Ed.). USA: Prentice Hall Publisher. Chapter 27: The Newborn at Risk: Conditions Present at Birth. pp. 923-956.

Mally, P., Sean, B., \& Hendricks-Muñoz, K. (2010). Clinical Issues in the Management of Late Preterm Infants. Current Problems in Pediatric and Adolescent Health Care, 40(9), 218-233.

Mardones, F., Marshall, G., Viviani, P., Villarroel, L., et al. (2008). Estimation of Individual Neonatal Survival Using Birthweight and Gestational Age: A Way to Improve Neonatal Care. Journal of Health, Population and Nutrition, 26(1), 54-63.

Mattson, S., \& Smith, J. (2011). Core Curriculum for Maternal Newborn Nursing (4th Ed.). St Louis: Elsevier Saunders. Chapter 17: The Newborn at Risk. pp. 347-356.

McLenan, D. (2007). In Rakel, R. \& Bope, E. (Eds.). Conn's Current Therapy 2007. Philadelphia PA: Saunders Elsevier. Section 16: Care of the High-Risk Neonate. pp. 1200-1210. 
Mohammed, S. (2010). Quality of Nursing Care for Neonates with Respiratory Distress Syndrome (Unpublished Master Thesis). Faculty of Nursing, Benha University, Egypt. pp. 45-64.

Morley, C., Davis, P., Doyle, L., Brion, L., \& Hascoet, J. (2008). Nasal CPAP or Intubation at Birth for Very Preterm Infants. The New England Journal of Medicine, 358(7), 700-708.

Mustafa, S. (2007). Quality of Nurses Performance in Neonatal Intensive Care Units (Unpublished Master Thesis). Faculty of Nursing, Benha University, Egypt, pp: 57-83.

Nettina, S. (2014). Lippincott Manual of Nursing Practice $\left(10^{\text {th }}\right.$ Ed.). Philadelphia PA: Lippincott Williams \& Wilkins. Chapter 44: Pediatric Respiratory Disorders. pp. 1479-1519.

Parajulee, S., \& Selvaraj, V. (2011). Assess Knowledge of Nurses Towards Cardio-Pulmonary Resuscitation in NICU at Bharatpur Nepal University Hospital. Journal of Clinical and Diagnostic Research, 5(8), 1585-1588.

Pillitteri, A. (2010). Maternal and Child Health Nursing: Care of the Childbearing and Childrearing Family ( $6^{\text {th }} E d$.). Philadelphia, PA: Lippincott Williams \&Wilkins. Chapter 26: Nursing Care of a Family with a High-Risk Newborn. pp. 698-741.

Potts, N., \& Mandleco, B. (2012). Pediatric Nursing: Caring for Children and Their Families (3rd Ed.). USA: Delmar, Cengage Learning. Chapter 24: Respiratory Alterations. pp. 791-836.

Register, C. (2002). A Survey of Neonatal Suction Techniques by Registered Nurses (Published Master Thesis). Marshall University, USA. pp. 52.

Ricci, S., \& Kyle, T. (2009). Maternity and Pediatric Nursing (1st Ed.). Philadelphia, PA: Lippincott Williams \& Wilkins. Chapter 24: Nursing Management of the Newborn at Risk: Acquired and Congenital Newborn Conditions. pp. 724-731.

Sadek, B. (2010). Evidence Based Guidelines for Care of Neonates with Respiratory Distress Syndrome (Unpublished Doctoral Thesis). Faculty of Nursing, Ain Shams University, Egypt. pp. 8996.

Sayed, H. (2009). Assessment of Nursing Care Giving for High Risk Neonates. (Unpublished Master Thesis). Faculty of Nursing, Ain Shams University. Egypt. pp. 62-71. 
Schraufnagel, D. (2010). Breathing in America: Diseases, Progress, and Hope, American Thoracic Society. Chapter 19: Respiratory Distress Syndrome of the Newborn, Retrieved May 23, 2014, 12:48 PM, from http://www.thoracic.org.

\section{جودة الرعاية التمريضية المقدمة للأطفالالمبتسرين الذين يعانون من متلازمة الضائقة التنفسية}

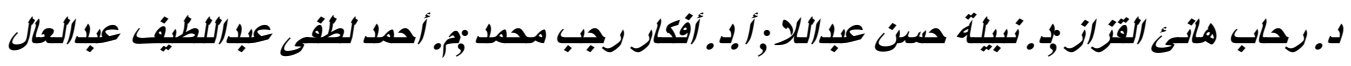

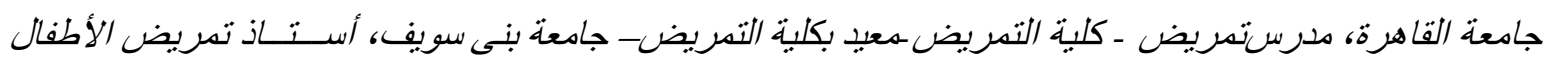
الأطفالكلبة التصريض - جامعة بورسعبي

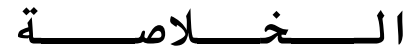

إن الأطفال المبتسرين أكثر عرضة لمشاكل التنفس عامةً ومتلازمة الضائقة التنفسية خاصة. فمتلازمة الضائقة التنفسية هى إضطر اب فى عملية التنفس نتيجة نقص في مادة السرفاكتنت. وقد أجريت هذة الدراسة الوصفية في وحدات الرعاية المركزة لحديثي الولادة بمستشفيات النصر، والتضامن ، وبورفؤاد العام فى محافظة بورسعيد. إذ تتألف العينة من 48 ممرضة و عدد 71 من الأطفال المبتسرين الذين يعانون من متلازمة الضائقة التنفسية. وقد تم قياس معلومات الممرضات بإستخدام إستمارة تقييم معلومات الممرضات فى حين أنه تم تقييم ممارساتهن بإستخدام قائمة ملاحظات مهار اتهن. بينما تم تجميع بيانات الأطفال المبتسرين من السجلات الطبية. وأثنارت نتائج الدراسة إلى أن أقل من ثلثي الممرضات ذوي معلومات ضعيفة؛ في حين أن مستوى ممارسات أكثر من نصفهن كان ضعيفاً. ووجدت علاقة ذات دلالة إحصائية بين معلومات الممرضات ومستواهن التعليمي؛ و أيضاً كان هناك علاقة ذات دلالة إحصائية بين ممارسات الممرضات ومستو اهن التعليمي. وأوضحت نتائج الدر اسة أن هناك علاقة ذات دلالة إحصائية عالية بين معلومات الممرضات وممارساتهن. وأوصت هذة الدراسة بضرورة تطبيق برنامج تعليمي للممرضات فى وحدات حديثي الولادة وذلك لتحسيين مستوى معلوماتهن وممارساتهن، وكذلك تحسين جودة الر عاية التمريضية لحديثى الو لادة ذوى الخطورة العالية. الكلمات الداللة المرشدة :الطفل المبتسر،جودة الرعاية التصربضية، متلازمة الضائقة التنفسية 